\title{
Household Livelihood and Coping Mechanism During Drought among Oraon Tribe of Sundargarh District of Orissa, India
}

\author{
Suchismita Mishra \\ Department of Anthropology, Sambalpur University, Sambalpur 768 019, Orissa, India \\ E-mail: suchismita44@gmail.com
}

KEYWORDS Livelihood; coping; drought; tribal

\begin{abstract}
The present study attempted to report the livelihood and coping strategies at the household level during drought among Oraon tribe living in Sundargarh district of Orissa. The study is based on both quantitative and qualitative data collected from households and key-informants in the community. These data were based on the livelihood and coping strategies during the drought and lean period during the year 2002. The scanty of rainfall due to irregular monsoon in the current Kharif crop season (2002) has resulted in massive crop failure and subsequent acute drought condition. During this period, the Oraons of this area have implemented a range of livelihood and coping strategies to reduce their vulnerability. The present study reports some rituals that followed by Oraons to appease, the Lord Indra (the god of rain). In addition, some social support system to cope up during drought also existed in this tribe. At household level, reduction of food consumption and change in the pattern of food consumption are important strategies to cope up with low resources. Majority of people in this area changed their occupation, as agriculture is failed due to drought. Also many households either sold or mortgaged their lands and household assets. Some of the people, including young children migrated temporarily to other places for livelihood. Various studies from other drought prone areas were reviewed and discussed briefly in the light of present study results.
\end{abstract}

The incidence of poverty in India is usually measured as the percentage of the population that falls below the poverty line. This incidence in Orissa is $47.15 \%$ (Government of Orissa, 2005). Scheduled tribes and scheduled castes, feature prominently amongst the poor in India. In the Indian context, it is important to note that the government has been interventionist and tried to influence economic processes in favour of rural areas. Small-scale enterprise, co-operative enterprise, and growth points have all been favoured by policy (soft loans, tax breaks etc.) in an attempt to make these income opportunities accessible to lower income groups and to rural areas. It is widely argued now that these distortive policies have acted as brake on broader economic growth (Gordon et al., 2001). However, more vulnerable and poor communities would be expected to have more diversified livelihoods. There is a growing literature showing that rural people in developing countries do indeed have very diverse income sources, particularly in difficult situation (Ellis, 2000). A review by Rani and Dodia (2001) considered the evidence on coping strategies in some drought prone rural India. It shows that one of the most favoured mechanisms is that of diversifying into non-farm activities and seasonally migrating to other areas. The literature also clearly shows that the households that are badly hit are those of small, marginal farmers and landless households and those belonging to lower castes, which also diversify first. In diversifying into non-farm activities, households simultaneously draw upon social relationships and informal credit networks. The social relationships and the traditional support system on caste lines continue to serve as a means of support in various ways, though these networks are weakening in many places. Interest rates rise during droughts, making it very difficult for the poor households to borrow, though these networks continue to be effective during normal years. The consumption needs of farmers during lean periods are partially met by drawing upon the reserve assets, which they build up during peak seasons. In addition, it is expected that during drought period, households also reduce their food intake and expenditure on social and religious commitments. With this background, the present study attempted to report the livelihood and coping strategies at the household level during drought among Oraon tribal people living in Sundargarh district of Orissa.

\section{AREA, PEOPLE AND METHODS}

Sundergarh, one of the 30 districts of Orissa, located in the northern extremity of Orissa, lies between $21^{\circ} 32^{\prime}$ and $22^{\circ} 32^{\prime}$ north latitudes and 
$83^{\circ} 32^{\prime}$ and $85^{\circ} 22^{\prime}$ east longitudes. The population of the district is $18,29,412$ and of this population, tribals constitute around $51 \%$ (Census of India, 2001). The present study has been undertaken in an Oraon tribal dominant village, namely Alapaka. In Oraon language, the meaning of Alapaka is tiger's cave. The area is named as Alapaka because it is said that once many tigers were lived in the area. Many displaced people of Mandira dam have been rehabilitated in this area. This indicates dense forest might have existed once, but presently this area is covered with thin forest.

Oraon is one of the major tribal groups in India. They inhabit the states in central and eastern India, including Jharkhand, Madhya Pradesh, Orissa, Chhattisgarh and West Bengal. Traditionally, they depended on the forest for their ritual and economic livelihood, but in recent times they have became settled agriculturists. Their usual diet consists of rice, pulses and vegetables. Fish and meat are occasionally consumed. The striking feature is that leaves, flowers, seeds, roots and fruits are an integral part of the Oraon diet. These are procured from the forest. The Oraons speak their own language Kurukh, which belongs to the Dravidian linguistic family. Though Oraons have their own religion, a considerable number of these people are Christians. The Oraon people have a rich and vast range of folk songs, dances and tales, as well as traditional musical instruments.

This study adopted various methods of data collection, which undertook during NovemberDecember 2002. Initially census of the village is undertaken. Subsequently, the quantitative data were collected from interviewing the heads of the household with a structured questionnaire $(n=20)$. The qualitative data were collected through observation and case studies. Five case studies were used to obtain information on various coping strategies. Also, data were collected from $20 \mathrm{key}$-informants in the community (including schoolteachers, sarpanch and ward members of panchayat, local doctors and members of local non-governmental organization) through formal and informal discussions. The data were collected with references to the details of livelihood and coping strategies during the lean period during the year 2002.

\section{RESULTS}

The scanty of rainfall due to irregular monsoon in the current Kharif crop season (2002) has resulted in massive crop failure and subsequent acute drought condition in larger parts of Orissa, including the study area. The Revenue authority in the Alapaka revenue circle has reported about 70 to 75 percent paddy loss. Due to frequent drought and crop failure the Oraons of this area have implemented a range of coping and livelihood strategies to reduce their vulnerability.

Drought is a regular phenomenon in our sample area. So, the Oraons keep a vigilant eye upon the nature and prepare themselves to face the unavoidable calamity. On the basis of their traditional knowledge system, they assess the rainfall of the year. It is believed that if the banyan tree (Ficus benghalensis) started shedding leaves from top to down it indicates threat of famine. If leaves started falling from down to up, there will be good rains. Further, if the wild pests damage the young leaves and buds of wild trees drastically, people think that the rainfall will be irregular. Similarly, if there are rows of black ants most often, it implies the sign of bad rains in future. If the rain comes from northeast direction, it indicates chances of good rains. All these predictions have implications on their livelihood strategies. In order to get good rains, they appease lord lndra, the god of rain. For this purpose, they perform a ritual. The ritual will be celebrated on a date, fixed by the village priest, Kalo. On that day, all the women of the village go to the top of the nearby hill and pray first to the Agni debta (the god of fire). They offer milk to all the directions in the hilltop, where the ritual is being done. While returning home, every woman will be given a little water from a tumbler of water, which was offered in the ritual by kalo. After returning home, they add little more water to it. This water will be considered as sacred and sprinkled on the roofs of their houses. People believe that doing like this will please the lord Indra.

In the study area, a social support mechanism exists to cope up during drought. It is by the means of co-operation, reciprocity and mutual support amongst the community members. A form of patron-client relationships also exists and it is exploitative in nature but serve to ensure that people have access to work in return of cash or kind. Some of the case studies reflected this type of mechanism. This helps them in troublesome situations like food crisis or lean season. When people like old men are unable to do work or who have no food to eat, other members in the 
community make arrangements to provide some work to get food. For example, the old people, who cannot do hard work, in the field or as daily labourer, will be given works like looking after the cattle. In drought like situations all villagers jointly strive against the situation by helping each other. However, there are some strategies followed by these people at the household level to cope during the drought.

\section{Reduction of Food Consumption and Change of Food Consumption Pattern}

In the crisis period, due to scarcity of food they have little amount of food to eat. The labour price is less and market (consumer) price is very high. So in this situation they have to cope with the situation. As the market price is very high, they cannot buy the required amount of food. Of the study households, 35\% consumed kanki (broken rice) instead of rice. The broken rice is cheaper than rice by half. Other households have used the previous year's stock of paddy. About $25 \%$ of households have reduced their quantity of consumption to one fourth of the normal and $40 \%$ have reduced the quantity of consumption to half. Also during this period, people reduced their dependency on market for purchasing food items. They managed with low cost foods. Most of the Oraon families consumed the stocked pulses and vegetables grown in their fields/ kitchen garden.

In this area, adults normally consume food three times a day and children consume four times a day, but there is no fixed time for children. Some households $(20 \%)$ avoided breakfast and many people changed breakfast to low-cost foods like broken rice (40\%), puffed rice (5\%) and tea (25\%). As lunch, many people (95\%) used to take watery rice locally called pakhal with or without a curry made of vegetables. Pakhal is made by preserving the previous days' leftover rice by adding water to it. Some households $(5 \%)$ did not consume lunch during the lean season. Similarly, some households $(15 \%)$ did not take dinner. Majority of households $(65 \%)$ took rice with some curry made of vegetables as dinner. Some households $(20 \%)$ consumed only locally made liquor during dinner. It is to be noted that this liquor costs lesser than rice.

To overcome the food crisis period, the Oraons stored food and other crops from previous crop and used them during time of shortage.
Usually these people store cereals and pulses, which they produce for the crisis period. During lean season, they do not get vegetables and green leafy vegetables. So they managed with powders of leaves and long lasting food preparations. These include tamarind, dry mahua (Madhuca indica) flowers, bari (a cake made of pulses), kako (a jelly cake made from mahua flowers), etc. Instead of rice they consumed these food items including dry kendu fruits, mahua flowers, char (Buchanania latiafolia) seeds, sal (Shora robusta) seeds, etc.

\section{Change of Occupation}

The primary occupation of the Oraon in the study area is agriculture. But due to crop failure, many households ( $60 \%$ of the study households) tried to survive by changing their occupation. Some people $(25 \%)$ depended on selling nontimber forest produce and firewood in nearby villages. The remaining respondents reported that they joined wage labouring for the first time in a compulsive situation. As these people do not know any skilled work due to illiteracy, they worked as non-skilled labourers. A very few people are engaged in vegetable cultivation and selling. Due to crop failure and non-availability of wage labour, some people depended on selling forest-based products including firewood and timber in compulsive circumstances. This might has contributed to the ongoing process of deforestation. Also, with the increase in the number of forest produce collectors, forest products are no longer easily available. On the other hand due to increasing people who sell forest products in the local market, the price of forest products have declined considerably. Taking advantage of the situation the middlemen have accumulated large profits. In the study village, some of the local politicians have involved in this business as middlemen.

\section{Mortgage of Land and Other Household Assets}

Due to regular crop failure, people perceived that the land is no more very important. To over come from the present situation many people are forced to mortgage their land and other household assets like ornaments, utensils, etc. In the study village, many people mortgage their land and other household assets to the local sahukar or to the gountia (pan businessman). In 
the study area, mostly Mahakud people do this business. There are two types of land mortgage systems in the study area. They are: (i) Udana: In this type of land mortgage, people mortgage the land for a specific time period (few months to some years) for specific amount. During that period the landowner (mortagagee) does not have any right on his land as he has given mortgage. The mortagager will cultivate if he wishes and profit or loss on the land will be carried on by him. (ii) Jharpeski: In this type of mortgage, people mortgage the land for a specific amount of money. When the amount along with prescribed interest is returned back by the mortagagee, he will get back the land. In the study village, people prefer the second type of mortgage. In case of mortgage of household assets and ornaments, when the required amount is given back to the sahukar with interest, they get their things back.

\section{Borrowing Loan with the Condition to Repay the Loan in the Form of Labour and Forthcoming Agriculture Produce}

There is no demand for wage labour and very few people are engaged as daily wage labourer. Many people are workless most of the days especially during lean season. So in those days to get food, they borrowed loan from the contractors or the person under whom they work. They borrowed money with the understanding that for this money, they will work for some extra days as wage labourer. The people, who are agriculturists, returned the amount by giving some amount of crop after harvest. It is known from the data that even in normal productive years, many people depended on loans for their survival.

\section{Selling of Goods}

The present situation of food scarcity has forced many Oraon people to dispose of their stored food grains to the local rich people like sahukars or gauntia. Due to their feeble economic condition they borrowed money from these sahukar and gauntia by promising to repay the money in the form of crop or money. Prior to harvest, some people mortgaged their standing crops at very low amounts. Further after harvesting, they either consumed or sold their grains due to various reasons. Also due to crop failure, they cannot pay back. As a result they sold their land and household asserts. During recent period, people sold their land, plants, food products that they store, cattle, utensils and ornaments at a very low price. Mahua plant is given more importance in this community and it is an economic asset. People drink liquor made of mahua flowers and mahua flowers cost six rupees per kilogram. And hence mahua tree is more important in this area, as comparison to other fruit bearing trees.

\section{Casual and Permanent Migration}

Due to regular crop failure because of the drought, the people lost their purchasing power, investment capacity and above all economic and ecological base in their native place. Also, they are leaving their agricultural land barren and consequently, wage labouring is also decreasing day-by-day. Hence, some of the people migrated to distant places within and outside the state of Orissa in search of work. Another consequence of this situation is that from this study village, five girls have migrated to Mumbai in search of work (construction work). Some middlemen are involved in this affair. They give the hope that they provide them work in Mumbai, but actually it seems that these girls were exploited sexually. From in-depth interviews with key-informants in the community, it is known that Pragati, a nongovernmental organisation tried to bring back these girls. From data, it is revealed that some of the respondents are preferred to work outside $(25 \%)$ or send their wives $(25 \%)$ or children $(30 \%)$ to work, as migrants during lean season.

\section{DISCUSSION}

The literature on livelihood and coping during drought and difficult situations highlighted the micro-level household strategies. Most of the strategies use economic principles to explain household behaviour, whereby household assets are transformed by household activities into consumption outcomes (Gordon et al., 2001). Chambers and Conway (1992) stated that a livelihood comprises the capabilities, assets (stores, resources, claims and access) and activities required for a means of living. Ellis (2000) emphasizes the access of individuals and households to different types of capital, opportunities and services. Thus a livelihood comprises the assets (natural, physical, human, 
financial and social capital), the activities, and the access to these (mediated by institutions and social relations) that together determine the living gained by the individual or household. A livelihood perspective has, for example, largely superseded the farming systems framework, partly because of increasing recognition that rural livelihoods often include significant non-farm activities also, particularly in drought type of situations. The literature reveals that several types of livelihood and coping models have been put forward (Sen, 1981; Chambers, 1988; Swift, 1989; Kabeer, 1991; Davies, 1996; Carney, 1998; Barrett et al., 2001). Livelihood models focus on the relationship between assets (also capitals, factors), activities (strategies, production, exchange, etc.) and consumption outcomes (entitlements, consumption bundles, well-being, utility, income) within a mediating environment (Gordon et al., 2001). The Department for International Development (DFID) adopted a model of livelihood and coping. This model places community/household-based assets into five categories, namely, human capital, physical capital, social capital, financial capital and natural capital (Carney et al., 2000). A study by Department for International Development's Natural Resources Systems Programme from rural areas of Andhra Pradesh and Rajasthan revealed numerous examples of how rural people combine their use of these different assets to pursue different livelihoods (Gordon et al., 2001). Roads and transport, for instance, clearly influence access to markets. For example, the Oraons are enable to market various forest produce in nearby villages. Also it facilitates daily or longer-term travel/migration for other employment. The seasonal and circular type of migration that seen in Oraons, has long been part of the livelihood strategy across India. It is evident from major studies, like study of Andhra Pradesh (Rao, 1994), study of migration in Western Bihar (de Haan, 2002), study on labourer from Bundelkhand (Srivatsava and Ali, 1981) etc. The transforming structures and processes are the mediating influences external to the household. Transforming structures and processes can usefully be classified as operating at different levels, such as macro (e.g. national government policy), meso (e.g. state policies and programmes) and micro (e.g. local land-use plans). Markets also exert a major influence on livelihoods through changes in relative prices and terms of trade. In the Oraon community, these resulted in change in food consumption pattern. Majority of the households quantitatively reduced the consumption of food and some changed the pattern of food consumption such as from using rice to use of broken rice. Thus the objectives of livelihood and coping strategies vary within and across the situations. They include more income, increased well-being, reduced vulnerability, improved food security and more sustainable use of natural resource base (Gordon et al., 2001). A household may have a particular outcome as its objective, but the actual outcome may differ from the objective. It is also important to recognize that households may have both short-term and long-term objectives. Household coping strategies may address short-term objectives. However, people's objectives are likely to vary, depending on their livelihood strategies and circumstances. However, there has been surprisingly little research in India into what people's objectives, or desired outcomes, actually are. In a review it is postulated that for many people there is a hierarchy of three objectives or priorities, all of which can overlap and co-exist but as the lower ones are more and more met, so the higher ones become more significant. They are: survival (based on stable subsistence), security (based on assets and rights) and selfrespect (based on independence and choice). Once the first is achieved, people tend to pursue the second and third (Chambers et al, 1989). Changes in the external environment can affect assets, activities or outcomes. The resultant changes in behaviour are known as coping strategies. If coping behaviour is constantly necessary, then the livelihood strategy becomes a survival strategy, leading to erosion of assets and destitution (Turton, 2000). Poor households in risky environments adopt coping strategies to protect their livelihoods. These strategies include, intensification of existing income activities, diversification into new activities, migration, drawing upon social relationships and informal credit networks, drawing upon assets (stores or, in extremis, productive assets) and adjusting consumption patterns etc. Many of these strategies are noticed among Oraons of the present study area. Rani and Dodia (2000) considered the evidence on coping strategies in rural India. It shows that one of the most favoured mechanisms is that of diversifying into non-farm activities and seasonally migrating to other areas. 
Diversification into non-farm activities is of a temporary and permanent nature depending upon the severity of the situation. Like the present situation, the households that are badly hit are those of small/marginal farmers, landless households and those belonging to lower castes, those also diversify first. This phenomenon is not specific to any particular region but is observed in many droughts prone areas across the different countries (Gordon et al, 2001). However, Lanjouw and shariff (200) observed that lower castes are under-represented in better-paid non-farming works and concluded that there are constraints on access to non-farming employment in India. In diversifying into non-farm activities, households simultaneously draw upon social relationships and informal credit networks. The social relationships and the traditional support system along caste lines continue to serve as a means of support in various ways, though these networks are weakening. Interest rates rise during droughts, making it very difficult for the poor households to borrow, though these networks continue to be effective during normal years. The consumption needs of farmers during poor years are partially met by drawing upon the reserve assets, which they build up during peak seasons. These may take the form of savings in cash or inkind (e.g., stored grains), productive assets (such as livestock or land), and non-productive assets (such as jewellery). In drought years, households also reduce their food intake and expenditure on social and religious commitments. The reduction in food intake is more prominent among the women, and smaller farmers. Thus it is clear from the data that the Oraon households experience quite different pressures and opportunities that adopted as livelihood and coping strategies. However many factors, which are to be studied in-depth, influence the choices of these opportunities made across the households.

\section{ACKNOWLEDGEMENTS}

The author acknowledges Prof. D.K. Behera, Head of the Department of Anthropology, Sambalpur University, Sambalpur for his encouragement and support. Also, she is thankful to Dr. P.N. Panda, Department of Anthropology, Sambalpur University, Sambalpur for his guidance during this study.

\section{REFERENCES}

Barrett, C. B., T. Reardon and P. Webb. 2001. "Nonfarm income diversification and household livelihood strategies, in rural Africa: concept, dynamics and policy implications." Food Policy, 26: 315-331.

Carney, D. 1998. "Implementing the Sustainable Livelihoods Approach," in: D. Carney (ed.), Sustainable Rural Livelihoods: What contribution can we make? London: DFID.

Carney, D., M. Drinkwater, T. Rusinow, K. Neefjes, S. Wanmali and N. Singh. 2000. Livelihoods Approaches Compared (Draft): A brief comparison of the livelihoods approaches of the UK Department for International Development (DFID), CARE, Oxfam and the United Nations Development Programme (UNDP) Mimeo.

Chambers, R. 1988. Sustainable Livelihoods, Environment and Development: Putting Poor People First, IDS Discussion Paper, No 240.

Chambers, R. and G. Conway. 1992. Sustainable Rural Livelihoods: Practical Concepts for the 21st Century. IDS Discussion Paper, No. 296. IDS, Brighton.

Davies, S. 1996. Adaptable Livelihoods: Coping with Food Insecurity in the Malian Sahel. Basingstoke: Macmillan Press.

De Haan, A. 2002. "Migration and livelihoods in historical perspectives: a case study of Bihar, India". Journal of Development Studies, 38: 115-142.

Ellis, F. 2000. Rural Livelihoods and Diversity in Developing Countries. Oxford: Oxford University Press.

Gordon, A., C. Conroy, S. Iyengar, V. Lobo, U. Rani and G.B. Rao, 2001. Household livelihood and coping strategies in semi-arid India: synthesis of macroand micro- level findings. No. NRSP Project R7558. London: Natural Resources Systems Programme, Department for International Development.

Government of Orissa. 2005. Economic survey, 2004-05. Directorate of Economics and Statistics. Planning and Coordination Department. Bhubaneswar: Government of Orissa.

Kabeer, N. 1991. Gender, Production and Well-Being: Rethinking the Household Economy, IDS Discussion Paper 288. Brighton: Institute of Development Studies.

Lanjouw, P. and A. Shariff. 2002. Rural non-farm employment in India: access, incomes and poverty impact. NCAER Working Paper No. 81, New Delhi: National Council of Applied Economic Research.

Rani, U. and M. Dodia. 2000. Understanding Coping Strategies in Semi-Arid Areas: A Review of Empirical Literature. Ahmedabad: GIDR.

Rao, O. 1994. Palansoor labour: a study of migrant labour Mahabubuagar districts. Hyderabad: Council for Social Development.

Sen, A. K. 1981. Poverty and Famines: An Essay on Entitlements and Deprivation. Oxford: Clarendon Press.

Srivatsava, R.C. and J. Ali. 1981. "Unskilled migrants, their socioeconomic life and patterns of migration," (pp. 264-283) in R.B. Mandal (ed.), Frontiers of Migration Analysis. New Delhi: Concept Publishing House.

Swift, J. 1989 Why are Rural People Vulnerable to Famine? IDS Bulletin, 20(2): .8-15.

Turton, C. 2002. Sustainable livelihoods and project design in India. Working paper No. 127, London: Overseas Development Institute (ODI). 